\title{
Correction to: Selective killing of circulating tumor cells prevents metastasis and extends survival
}

\author{
Yi Rang Kim', Jung Ki Yoo ${ }^{2,3}$, Chang Wook Jeong ${ }^{4}$ and Jin Woo Choi ${ }^{2,3^{*}}$
}

\section{Correction to: J Hematol Oncol}

\section{https://doi.org/10.1186/s13045-018-0658-5}

The original article [1] contains an inadvertent omission in the Funding declaration. The authors would like to amend the Funding statement to the following:

\section{Funding}

This work was supported by the grants from Kyung Hee University (KHU20170844 for JW Choi) and the National R\&D Program for Cancer Control, Ministry of Health and Welfare, Republic of Korea (HA17C0039 for YR Kim, CW Jeong, and JW Choi).

\section{Author details}

'Department of Hematology/Oncology, Yuseong Sun Hospital, Daejeon 34084, Republic of Korea. ${ }^{2}$ Department of Pharmacology, College of Pharmacy, Kyung Hee University, Seoul 02447, Republic of Korea. ${ }^{3}$ Department of Life and Nano-pharmaceutical Sciences, Kyung Hee University, Seoul 02447, Republic of Korea. ${ }^{4}$ Department of Urology, Seoul National University Hospital, Seoul 03080, Republic of Korea.

Received: 18 December 2018 Accepted: 18 December 2018 Published online: 09 January 2019

\section{Reference}

1. Kim YR, et al. Selective killing of circulating tumor cells prevents metastasis and extends survival. J Hematol Oncol. 2018;11:114 https://doi.org/10.1186/ s13045-018-0658-5.

\footnotetext{
* Correspondence: jinwoo.ch@khu.ac.kr

2Department of Pharmacology, College of Pharmacy, Kyung Hee University, Seoul 02447, Republic of Korea

${ }^{3}$ Department of Life and Nano-pharmaceutical Sciences, Kyung Hee

University, Seoul 02447, Republic of Korea

Full list of author information is available at the end of the article
}

C The Author(s). 2019 Open Access This article is distributed under the terms of the Creative Commons Attribution 4.0 International License (http://creativecommons.org/licenses/by/4.0/), which permits unrestricted use, distribution, and reproduction in any medium, provided you give appropriate credit to the original author(s) and the source, provide a link to the Creative Commons license, and indicate if changes were made. The Creative Commons Public Domain Dedication waiver (http://creativecommons.org/publicdomain/zero/1.0/) applies to the data made available in this article, unless otherwise stated. 